\title{
Performance comparison of beam-column joints with different concretes
}

\author{
Wu Jun ${ }^{1}$, Mu Guohui ${ }^{1}$, Zhang Mingda ${ }^{1}$, Wang Sijin ${ }^{1}$, Ma Jun ${ }^{1}$, Ju Yanzhong ${ }^{2}$, Wang Dehong ${ }^{2}$ \\ ${ }^{1}$ State Grid Zhejiang Ningbo Fenghua Electric Power Supply Company Limited, Ningbo 315599; \\ ${ }^{2}$ School of Civil Engineering and Architecture, Northeast Electric Power University, Jilin, 132012
}

\begin{abstract}
With the development of concrete materials, high strength concrete (HSC) and fiber reinforced concrete (FRC) are more and more used in reinforced concrete frame structures. This paper collected the test results of normal concrete (NC), HSC and reactive power concrete (RPC) beam joints. The performances of different concrete joints were compared and analyzed from two aspects of failure process and characteristics and shear deformation. The results showed that the ratio of through-crack load to shear capacity of NC joints is about $0.75-0.80$, while that of RPC joints through-crack is close to shear capacity. The randomly distributed steel fibers of RPC like dispersed steel bars can effectively restrain the development of oblique cracks in the core area of joints. When the ultimate load is reached, the average shear angle of NC joints is much larger than that of RPC and steel fiber reinforced concrete joints. The small deformation of joints ensures the stiffness of RPC and steel fiber reinforced concrete joints. However, because there is no coarse aggregate in RPC, the occlusal interaction between the two sides of oblique cracks in the core area of RPC beam-column joints is obviously lower than that of $\mathrm{NC}$ joints.
\end{abstract}

\section{Introduction}

Beam-column joint is an important part of the structure, which plays the role of force transmission and connection to ensure the integrity of the structure. Under the action of earthquake, the shear force in the core area of the joint is usually large, which is usually several times that of the beam end and column end, and the shear failure of the joint core area is easy to occur[1]. In order to realize the "Strong joint weak member", the joint core area is usually equipped with more stirrups. With the development of civil engineering materials, high-strength steel bar [2, 3], fiber reinforced concrete $[4,5]$, high-strength concrete [6], fiber reinforced concrete [7-9] are more and more used in reinforced concrete frame structures to simplify the reinforcement in the core area of joints and facilitate construction. The change of material performance will lead to the change of structural deformation performance and even failure mode. Therefore, this article collected similar size, different beam-column joints of concrete material test results, analysis of normal concrete (NC), high strength concrete (HSC) and reactive powder concrete (RPC) the shear failure process and characteristics of normal concrete, steel fiber reinforced concrete and reactive powder concrete node shear deformation performance. It provides a reference for seismic design of fiber reinforced concrete beam-column joints such as RPC.

\section{Collection and statistics of test results}

In literature[10], The cube compressive strength of two high strength concrete beam-column joints BCJ5-0 and BCJ5-1 is $69.2 \mathrm{MPa}$ and $68.6 \mathrm{MPa}$, respectively. Beam section size $b_{b} \times h_{b}=150 \mathrm{~mm} \times 300 \mathrm{~mm}$, column section size $b_{c} \times h_{c}=200 \mathrm{~mm} \times 200 \mathrm{~mm}$. The tensile longitudinal bars of the beam are 2D16, the beam end and the beam top are symmetrical reinforcement, and the stirrups were 8@100; The longitudinal reinforcement of the column was 4D22, and the stirrup was 8@100; The stirrups in the core area of specimen BCJ5-0 were 2D8 double-leg stirrups, the core stirrups of specimen BCJ5-1 were 5D8 double-leg stirrups, and the yield strength of stirrups were $306.9 \mathrm{MPa}$. The main parameters and test results of the specimen were shown in table 1 . The method of beam end loading was adopted in the pseudo-static test.

\footnotetext{
$\overline{{ }^{*} \text { Corresponding author: }{ }^{a} \text { hitwdh@ }} 126 . c 0 m$
} 
Table 1. Main parameters and test results of specimens in reference [10]

\begin{tabular}{|c|c|c|c|c|c|c|c|c|}
\hline \multirow{2}{*}{ Specimen } & \multirow{2}{*}{$\begin{array}{c}\text { The cube } \\
\text { compressive } \\
\text { strength } f_{\text {cu }} \\
(\mathrm{MPa})\end{array}$} & $\begin{array}{c}\text { Axial } \\
\text { compression } \\
\text { ratio of column }\end{array}$ & $\begin{array}{c}\text { Core area } \\
\text { stirrup }\end{array}$ & $\begin{array}{c}\text { Shear } V_{\text {jcr }} \\
(\mathrm{kN})\end{array}$ & $\begin{array}{c}\text { The } \\
\text { shearing } \\
\text { angle } \gamma_{\mathrm{cr}} \\
(\mathrm{rad})\end{array}$ & $\begin{array}{c}\text { Phear } \\
\mathrm{V}_{\mathrm{j}} \\
(\mathrm{kN})\end{array}$ & $\begin{array}{c}\text { The } \\
\text { shearing } \\
\text { angle } \gamma_{\mathrm{m}} \\
(\mathrm{rad})\end{array}$ & $\begin{array}{c}\text { Failure } \\
\text { type }\end{array}$ \\
\hline BCJ5-0 & 69.2 & 0.3 & $2 \mathrm{D} 8$ & 214.0 & 0.00040 & 274.8 & 0.0046 & $\mathrm{JS}$ \\
\hline BCJ5-1 & 68.6 & 0.3 & $5 \mathrm{D} 8$ & 231.9 & 0.00021 & - & 0.0010 & $\mathrm{BF}$ \\
\hline
\end{tabular}

Note: In the failure types of beam-column joints, "BF" means that the failure of the specimen is bending failure at the end of the beam, and "JS" means that the failure of the specimen is shear failure in the core area.

There are 13 high-strength concrete beam-column joint specimens in literature[11]. The concrete cement was 52.5 MPa Portland cement, the coarse aggregate is limestone macadam with particle size $0.5 \sim 2.0 \mathrm{~cm}$, the concrete cube compressive strength was 58.64-66.77 MPa, and the axial compressive strength was 55.36 46.91 MPa. All specimens adopted the same geometrical size. The beam section size of the specimens was $\mathrm{BB} \times \mathrm{HB}=$ $150 \mathrm{~mm} \times 300 \mathrm{~mm}$, and the column section size was $b_{c} \times h_{c}$
$=200 \mathrm{~mm} \times 200 \mathrm{~mm}$. The joint parameters include the stirrup ratio and axial compression ratio in the core area, the stirrup ratios in the three core areas were $1.15 \%, 1.54 \%$ and $2.69 \%$ respectively, the yield strength of stirrups was $307 \mathrm{MPa}$, and the axial compression ratio ranges from 0.285 to 0.814 . The main parameters and test results of the specimen were shown in table 2 . The method of beam end loading was adopted in the pseudo-static test.

Table 2. Main specimen parameters and test results in literature [11]

\begin{tabular}{|c|c|c|c|c|c|c|}
\hline Specimen & $\begin{array}{c}\text { The cube } \\
\text { compressive } \\
\text { strength } f_{\text {cu }} \\
\text { (MPa) }\end{array}$ & $\begin{array}{c}\text { Axial } \\
\text { compression } \\
\text { ratio of } \\
\text { column }\end{array}$ & $\begin{array}{c}\text { Core area } \\
\text { stirrup }\end{array}$ & $\begin{array}{c}\text { Cracking } \\
\text { shear force } \\
\mathrm{V}_{\text {jcr }}(\mathrm{kN})\end{array}$ & $\begin{array}{c}\text { Shear capacity } \\
\mathrm{V}_{\mathrm{j}}(\mathrm{kN})\end{array}$ & $\begin{array}{c}\text { Failure } \\
\text { type }\end{array}$ \\
\hline $\mathrm{J} 3-50$ & 50.45 & 0.285 & $5 \mathrm{D} 6.5$ & 140.01 & 285.74 & BJ \\
\hline $\mathrm{J} 4-50$ & 52.30 & 0.361 & $5 \mathrm{D} 6.5$ & 153.43 & 313.13 & BJ \\
\hline $\mathrm{J} 4-30$ & 51.34 & 0.374 & $8 D 6.5$ & 155.27 & 316.88 & BJ \\
\hline $\mathrm{J} 5-80$ & 51.30 & 0.467 & 4D6.5 & 172.61 & 352.27 & BJ \\
\hline $\mathrm{J} 5-50$ & 53.42 & 0.449 & 5D6.5 & 176.19 & 359.58 & BJ \\
\hline $\mathrm{J} 6-80$ & 51.63 & 0.558 & 4D6.5 & 196.49 & 370.73 & BJ \\
\hline $\mathrm{J} 6-50$ & 46.91 & 0.614 & 5D6.5 & 175.90 & 331.89 & BJ \\
\hline $\mathrm{J} 6-30$ & 53.36 & 0.54 & $8 D 6.5$ & 192.41 & 363.03 & BJ \\
\hline J7-80 & 46.91 & 0.716 & 4D6.5 & 167.14 & 315.35 & BJ \\
\hline J7-50 & 52.80 & 0.636 & 5D6.5 & 190.58 & 359.58 & BJ \\
\hline J7-30 & 47.20 & 0.712 & 8D6.5 & 187.51 & 353.80 & BJ \\
\hline J8-50 & 55.36 & 0.744 & 5D6.5 & 195.47 & 368.81 & BJ \\
\hline J8-30 & 47.20 & 0.814 & 8D6.5 & 177.73 & 335.34 & BJ \\
\hline
\end{tabular}

Note: In the failure type of beam-column joint assembly, "BJ" means that the failure of the specimen is the joint failure of the plastic hinge at the beam end and the shear in the core area of the joint.

There were six reinforced concrete beam-column joints in literature [12], and the cube compressive strength of two specimens with shear failure of joints was 36.0 MPa. The section size of the specimen beam was $b_{b} \times h_{b}$ $=150 \mathrm{~mm} \times 300 \mathrm{~mm}$, and the section size of the column was $b_{c} \times h_{c}=200 \mathrm{~mm} \times 200 \mathrm{~mm}$. The longitudinal reinforcement of the beam was 3D12, the reinforcement ratio was $0.96 \%$, the top and the end of beam were symmetrically reinforced; The longitudinal reinforcement of the column was $8 \mathrm{~A} 12$ and the cross-section reinforcement ratio was $2.26 \%$. The stirrups in the core area of specimen ZHJ4 were 2D6+3D4@60 composite stirrups (volume stirrup ratio 1.0\%), and the core stirrups of specimen ZHJ5 were 4D6@70 double-leg stirrups (volume stirrup ratio $1.21 \%$ ). The yield strength of beam and column longitudinal reinforcement was $360.2 \mathrm{MPa}$, the yield strength of D6 stirrups is $350 \mathrm{MPa}$, and the ultimate strength of D4 stirrups is $640.6 \mathrm{MPa}$. The designed axial compression ratio of the column was 0.33 . The main parameters and test results of the specimen were shown in table 3. Quasi-static tests were carried out using a four-link test system. 
Table 3. Main specimen parameters and test results in literature [12]

\begin{tabular}{|c|c|c|c|c|c|c|}
\hline Specimen & $\begin{array}{c}\text { The cube } \\
\text { compressive } \\
\text { strength } f_{\text {cu }} \\
(\mathrm{MPa})\end{array}$ & $\begin{array}{c}\text { Axial } \\
\text { compression } \\
\text { ratio of } \\
\text { column }\end{array}$ & Core area stirrup & $\begin{array}{c}\text { Cracking } \\
\text { shear force } \\
\mathrm{V}_{\text {jcr }}(\mathrm{kN})\end{array}$ & $\begin{array}{c}\text { Shear } \\
\text { capacity } \mathrm{V}_{\mathrm{j}} \\
(\mathrm{kN})\end{array}$ & $\begin{array}{c}\text { Failure } \\
\text { type }\end{array}$ \\
\hline ZHJ1 & 35.7 & 0.33 & 2D6+3D4@60 & 178.3 & - & BF \\
\hline ZHJ2 & 35.7 & 0.33 & 2D6+3D4@60 & 160.5 & - & BF \\
\hline ZHJ3 & 35.7 & 0.33 & 2D6+3D4@60 & 160.5 & - & BF \\
\hline ZHJ4 & 36.0 & 0.33 & 2D6+3D4@60 & 166.4 & 351.0 & JS \\
\hline ZHJ5 & 36.0 & 0.33 & D6@70 & 178.3 & 352.2 & BJ \\
\hline ZHJ6 & 36.0 & 0.33 & D6@70 & 208.1 & - & BF \\
\hline
\end{tabular}

Literature [13] designed five beam-column joints specimens, four high-strength stirrups with $5 \mathrm{~mm}$ diameter of circular steel bar and $7 \mathrm{~mm}$ diameter of deformation steel bar in the core area, one common stirrups with
$6.5 \mathrm{~mm}$ diameter of HPB235 steel bar in the core area. Pseudo-static tests were carried out by column end loading. The main test results of this test were collated and calculated, as shown in table 4 .

Table 4. Main test results in literature [13]

\begin{tabular}{|c|c|c|c|c|c|c|}
\hline \multirow[b]{2}{*}{ Specimen } & \multirow[b]{2}{*}{$\begin{array}{l}\text { Loading } \\
\text { direction }\end{array}$} & \multirow[b]{2}{*}{$\begin{array}{l}\text { Cracking } \\
\text { shear force } \\
\mathrm{V}_{\text {jcr }}(\mathrm{kN})\end{array}$} & \multicolumn{2}{|c|}{ Peak value } & \multirow[b]{2}{*}{$\begin{array}{c}\text { Ultimate shear } \\
\text { angle } \\
\gamma_{\mathrm{m}}(\mathrm{rad})\end{array}$} & \multirow[b]{2}{*}{$\begin{array}{c}\text { Failure } \\
\text { type }\end{array}$} \\
\hline & & & $\begin{array}{c}\text { Shear } \\
\mathrm{V}_{\mathrm{j}}(\mathrm{kN})\end{array}$ & $\begin{array}{c}\text { The shearing } \\
\text { angle } \\
\gamma_{\mathrm{m}}(\mathrm{rad})\end{array}$ & & \\
\hline \multirow{2}{*}{ HRCJ-1 } & Positive & 377.62 & 655.55 & 0.0072 & 0.0079 & \multirow{2}{*}{ JS } \\
\hline & Negative & -378.75 & -657.43 & -0.0075 & -0.0115 & \\
\hline \multirow{2}{*}{ HRCJ-2 } & Positive & 378.00 & 679.71 & 0.0081 & 0.0136 & \multirow{2}{*}{ JS } \\
\hline & Negative & -377.62 & -692.06 & -0.0021 & -0.0090 & \\
\hline \multirow{2}{*}{ HRCJ-3 } & Positive & 376.11 & 691.42 & 0.0080 & 0.0128 & \multirow{2}{*}{ JS } \\
\hline & Negative & -378.75 & -690.29 & -0.0044 & -0.0073 & \\
\hline \multirow{2}{*}{ HRCJ-4 } & Positive & 375.73 & 657.43 & 0.0041 & - & \multirow{2}{*}{ JS } \\
\hline & Negative & -379.13 & -684.25 & -0.0040 & - & \\
\hline \multirow{2}{*}{ RCJ-1 } & Positive & 374.98 & 672.92 & 0.0079 & 0.0198 & \multirow{2}{*}{ JS } \\
\hline & Negative & -377.62 & -668.01 & -0.0037 & -0.0052 & \\
\hline
\end{tabular}

In the literature [14], the experimental results of RPC beam-to-column joints were introduced, in which 6 side joints and 4interiorjoints all suffered joint shear failure. The cross section dimensions of beam are $b_{b} \times h_{b}=$ $150 \mathrm{~mm} \times 250 \mathrm{~mm}$ and column are $b_{c} \times h_{c}=200 \mathrm{~mm} \times$ $200 \mathrm{~m}$. The top and the end of beam were symmetrically reinforced, and the longitudinal reinforcement of the column is 4D14. The main parameters and test results of the specimen are shown in Table 5. Pseudo-static tests were carried out by beam end loading.

Table 5. Main parameters and test results of specimens in reference [14]

\begin{tabular}{|c|c|c|c|c|c|}
\hline \multirow{2}{*}{ Specimen } & \multirow{2}{*}{ Joints types } & \multicolumn{2}{|c|}{ Cracking strength } & \multirow{2}{*}{$\begin{array}{c}\text { Shear capacity } \\
V_{\mathrm{j}}(\mathrm{kN})\end{array}$} & \multirow{2}{*}{ Failure type } \\
\cline { 3 - 4 } & & Positive & Negative & 271.20 & JS \\
\hline EJ-1 & Exterior joints & 121.74 & 173.91 & 302.63 & JS \\
\hline EJ-2 & Exterior joints & 191.30 & 173.91 & 232.88 & JS \\
\hline EJ-H1 & Exterior joints & 121.74 & 139.13 & 312.57 & JS \\
\hline EJ-H2 & Exterior joints & 149.57 & 156.52 & 229.84 & JS \\
\hline EJ-3 & Exterior joints & 156.52 & 113.04 & 216.92 & JS \\
\hline EJ-4 & Exterior joints & 142.61 & 149.57 & & BF \\
\hline EJ-5 & Exterior joints & 139.13 & 156.52 & & BF \\
\hline EJ-6 & Exterior joints & 173.91 & 191.30 & & BF \\
\hline EJ-7 & Exterior joints & 121.74 & 139.13 & & BF \\
\hline EJ-8 & Exterior joints & 156.52 & 173.91 & & BF \\
\hline EJ-9 & Exterior joints & 125.22 & 173.91 & & BF \\
\hline EJ-10 & Exterior joints & 139.13 & 156.52 & & JS \\
\hline J-1 & Interior joints & 156.52 & 175.31 & 374.82 & JS \\
\hline J-2 & Interior joints & 187.83 & 156.52 & 410.21 & JS \\
\hline J-3 & Interior joints & 187.83 & 187.83 & 380.91 & JS \\
\hline J-4 & Interior joints & 219.13 & 187.83 & 379.21 & \\
\hline
\end{tabular}




\section{Comparison of failure process and characteristics}

In the literature $[11,15]$ describing the failure process and failure characteristics of the core area of NC and HSC joints, the shear failure process of the core area of concrete joints is divided into four stages: initial crack, through crack, ultimate crack and failure.

In literature [11], when the axial compression ratio is less than 0.5 , the ratio of the initial crack load to the ultimate load in the core area of the interior joint is about 0.49 , and when the axial compression ratio is greater than 0.5 , the ratio of the initial crack load to the ultimate load is about 0.53 . In literature [16], the ratio of initial crack load to ultimate load of exterior joint specimens is 0.62 . In literature[12], the ratio of the initial crack load to the ultimate load in the core area of the interior joint specimen in the shear failure of the joint is 0.51 , and the ratio of the initial crack load to the ultimate load of the bending-joint shear failure specimen at the beam end is 0.47 . In literature[9], the average ratio of the initial crack load to the ultimate load of the 6 shear failure exterior joint specimens in the core zone is 0.66 , and the average ratio of the initial crack load to the ultimate load of the 4interiorjoint specimens is 0.55 , which is slightly higher than that of NC and HSC specimens. This is because the addition of steel fiber greatly improves the cracking strength of RPC, and the increase of the cracking load strength of steel fiber is greater than that of the ultimate bearing capacity of the joint.

When NC joints are cracked, the width of oblique crack in the core area is usually about $0.3 \mathrm{~mm}$, and the ratio of through crack load to shear bearing capacity is about $0.75 \sim 0.80[11,15]$. However, the shear force of RPC joints is close to the shear bearing capacity when the joints crack. Therefore, the shear failure process of the core area of RPC joints is divided into three stages in literature [14]. A similar phenomenon is also found in steel fiber reinforced concrete beam-column joints[17], Tang Jiuru thought that the through crack can be regarded as the ultimate state of the bearing capacity of steel fiber reinforced concrete joints, and it is suggested that the shear force of steel fiber reinforced concrete joints should be taken as the shear capacity of steel fiber reinforced concrete joints[18]. This is because the crack of ordinary concrete develops rapidly after cracking, while the steel fiber distributed randomly in RPC is like the dispersed reinforcement, which effectively restrains the

Table 6. Shear deflection angle of joint at different stage in literature [18]

\begin{tabular}{|c|c|c|c|c|c|}
\hline \multirow{2}{*}{ specimen } & \multirow{2}{*}{$f_{\mathrm{cu}}\left(\mathrm{N} / \mathrm{mm}^{2}\right)$} & \multirow{2}{*}{$\begin{array}{l}\text { Volume } \\
\text { content of steel } \\
\text { fiber }\end{array}$} & \multirow{2}{*}{$\begin{array}{c}\text { Stirrup in core } \\
\text { area }\end{array}$} & \multicolumn{2}{|c|}{$\begin{array}{l}\text { The shearing Angle }\left(\times 10^{-}\right. \\
\left.{ }^{3} \mathrm{rad}\right)\end{array}$} \\
\hline & & & & crack & $\begin{array}{l}\text { Through } \\
\text { crack }\end{array}$ \\
\hline SF1 & 21.3 & $1.2 \%$ & $\longrightarrow$ & 0.18 & 13.5 \\
\hline SF2 & 32.1 & $1.5 \%$ & 3D8@100 & 0.18 & 6.5 \\
\hline $\mathrm{RC} 4$ & 31.9 & 0 & 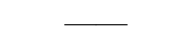 & 0.87 & 44.0 \\
\hline
\end{tabular}

development of oblique crack of RPC in the core area of joint.

The test results of HSC beam-column joints in literature [11] show that almost all the coarse aggregates intersecting with oblique cracks are split. It can be seen that the aggregate bears a large shear force before it is split, and the aggregate bite cooperation is significant. Because the RPC does not contain coarse aggregate, and the aggregate bite cooperation is weaker than the NC joint. In the failure stage, there is a small amount of crushed RPC falling out in the main oblique crack. There is a peeling phenomenon at the edge of the oblique crack.

\section{Comparison of shear deformation properties of joints}

According to the test results of RPC beam-column joints in literature [14], when the ultimate bearing capacity is reached, the average shear angles of the core areas of RPC exterior joints and interior joints are $2.73 \times 10^{-3} \mathrm{rad}$ and $2.64 \times 10^{-3} \mathrm{rad}$, respectively. When the failure occurs, the average shear angle of the core area of the exterior joint and the interior joint is $4.85 \times 10^{-3} \mathrm{rad}$ and $11.08 \times 10^{-3} \mathrm{rad}$, respectively. In the specimens of ordinary concrete beamcolumn joints with the same section size completed by Lv Xilin, the ultimate bearing capacity and the shear deformation angle of the core area of the joint are $4.17 \times 10^{-}$ ${ }^{3} \mathrm{rad}$ and $17.94 \times 10^{-3} \mathrm{rad}$, respectively, which are both larger than the shear deformation test results of the core area of RPC joints[12]. This is because the steel fiber in RPC effectively limits the shear deformation of the joint core area. The obvious reduction of joint deformation ensures a larger joint stiffness. In the two ordinary concrete joints completed in literature [19], when the ultimate load is reached, the proportion of the beam end displacement angle caused by the shear deformation in the core area to the total displacement angle is $27 \%$ and $32 \%$ respectively, which is much larger than that of the RPC joint test result. A similar phenomenon is also found in steel fiber reinforced concrete beam-column joints $[10,18]$. Table 6 shows the comparison of shear deformation angles of steel fiber and NC beam-column joints in different stages[18]. It can be seen from the results in the table that the shear deformation angle of $\mathrm{NC}$ joints is much larger than that of steel fiber reinforced concrete joints. The shear deformation angle of NC joints at initial crack is about 4.8 times that of steel fiber reinforced concrete joints, and 3.36.8 times at through crack. 


\section{Conclusion}

The test results of NC, HSC and RPC beam-column joints in the literature are collected and compared, and the following conclusions are drawn:

(1) Compared with NC beam-column joints, RPC beam-column joints have higher crack resistance, and the shear force is close to the ultimate bearing capacity. When shear failure occurs, there are more oblique cracks in the core area of the joint, less concrete spalling and better specimen integrity.

(2) The steel fiber in RPC can limit the shear deformation of the core area of joints to a large extent, so the shear deformation of RPC joints is smaller than that of $\mathrm{NC}$ joints with the same section size and failure type.

\section{Reference}

1. Wang G L, Dai J G and Teng J.G 2012 Shear strength model for RC beam-column joints under seismic loadi Eng Struct. 40 pp 350-360.

2. Alaee P and Li B 2017 High-Strength Concrete Interior Beam-Column Joints with High-YieldStrength Steel Reinforcements, J Struct Eng 143 pp 305-321.

3. Wang D.H, Ju Y.Z and Zheng W Z.2017 Strength of Reactive Powder Concrete Beam-Column Joints Reinforced with High-Strength (HRB600) Bars Under Seismic Loading, Strength Mater.49 pp 139151 .

4. Mady M , El-Ragaby A , and El-Salakawy E 2011 Seismic Behavior of Beam-Column Joints Reinforced with GFRP Bars and Stirrups, J. Compos. Constr. 15 pp 875-886.

5. Ghomi S K and El-Salakawy E 2019 Seismic Behavior of GFRP-Reinforced Concrete Interior Beam-Column-Slab Subassemblies, J. Compos. Constr. 2304019047.

6. Alaee P and Li B 2017 High-strength concrete exterior beam-column joints with high-yield strength steel reinforcements, Eng Struct. 145 pp 305-321.

7. Filiatrault A, Pineau S and Houde J 1995 Seismic behavior of steel-fiber reinforced concrete interior beam-column joints, ACI Mater. J. 92 pp 543-552.

8. Wang D, Ju Y and Shen H.2019 Crack Resistance
Properties of HPFRC Beam-Column Joints under Cyclic Load, Adv. Mater. Sci. Eng. pp 1-11.

9. Wang D, Ju Y, Zheng W and Shen H 2018 Seismic Behavior and Shear Bearing Capacity of Ultra-High Performance Fiber-Reinforced Concrete (UHPFRC) Beam-Column Joints, Appl. Sci. 8 p 810.

10. Shi K 2016 Seismic Behavior and Calculation Method of Steel Fiber Reinforced High-Strength Concrete Beam-Column Joints, Zhengzhou pp. 41-43, 142-143.

11. Zhao C W, Zhang, D H, Wang, T X and Chen D G 1993 Experimental Study on the Aseismatic Property of the Beam-Column Joints in High-strength Concrete Frame under Alternating Load, Journal of Shenyang Architectural and Civil Engineering Institute 9 pp 268-268.

12. Lv X L, Guo Z X and Wang Y Y 2001 Experimental Study on Seismic Behavior of Beam-column Subassemblages in RC Frame, J. Build. Struct.1 pp 27

13. Wang N 2015 Mechanical Behavior and Seismic Design of RC Columns Joints Confined with HighStrength Stirrups, Xian pp. 65-70+81.

14. Wang D H 2018 Study on Seismic Shear Bearing Capacity Calculation Method of RPC Frame Beamcolumn Joints, Harbin.

15. Tang, J R and Xu, X L 1988 Shear Strength of Reinforced Lightweight Aggregate Concrete Frame Joints and Anchorage of Beams Reinforcement, Build. Struct.(01) pp 4-10.

16. Said S H and Razak H A 2016 Structural behavior of $\mathrm{RC}$ engineered cementitious composite (ECC) exterior beam-column joints under reversed cyclic loading, Constr. Build. Mater. 107 pp 226-234.

17. Zhang W G and Chen T S 1989 A Study on Earthquake Resistance Behavior of Steel Fiber Reinforced Concrete Frame Joints, Constr. Build. Mater.(01) pp 35-45.

18. Tang J R, Yang K J and Zhou Q J 1989 Improvement on Behaviour of Frame Joints Using Steel Fibrous Reinforced Concrete, J. Build. Struct.(04) pp 37-44.

19. Li Z B, Guo E W, Zhou H Y and Bao X C 2009 The Seismic Behavior of Interior Beam-column Joints of RC Frame, World Earth. Eng.25 pp 61-66. 